\title{
Self-concept in University-level FL Learners
}

\author{
Patricia Arnaiz, University of Las Palmas de Gran Canaria, Canary \\ Islands, Spain \\ Felix Guillen, University of Las Palmas de Gran Canaria, Spain
}

\begin{abstract}
Existing research indicates that no other area of study presents as much of a threat to selfconcept as does foreign language learning. However, few foreign language learning studies have focused explicitly on self-concept. This study is timely in view of the current interest by the Spanish government in promoting foreign languages. It examined individual differences in the self-concept of 216 participants in a Spanish university context. Participants, English language learners, completed the Self-concept Scale Form 5-AF5 (Garcia \& Musitu, 2001). Self-concept levels both globally and in the academic, social and emotional dimensions were determined, and the relationship between self-concept, on the one hand, and gender, age, mark and language level on the other hand, was identified. The findings highlight the relevance of this type of study for informing language learning research. In addition, important implications for future research are discussed.
\end{abstract}

Keywords: Foreign Language Learning, Self-concept, Mark, Language Level

\section{Introduction}

ELF-CONCEPT IS ONE of the oldest constructs in the social sciences (James, 1896) and it is widely acknowledged that it plays a central role in all learning situations (Denissen, Zarrett, \& Eccles, 2007; Hattie, 1992; Marsh \& Yeung, 1997; Pajares \& Schunk, 2005). Improving students' self-concept must be seen as a major aim of education (O'Mara \& Marsch, 2006) and has been associated with many educational gains, such as better academic achievement, perseverance, coursework choice (Delugach, Bracken, Bracken, \& Schicke, 1992; Marsh \& Craven, 2006; Marsh \& Yeung, 1997; Valentine, DuBois, \& Cooper, 2004), and attitudes to learning (Burnett, Pillay, \& Dart, 2003).

Historically, self-concept research has been dominated by a unidimensional perspective in which self-conceptions were considered to be relatively consistent and undifferentiated across social, academic, physical, and other domains (Byrne, 1984; Coopersmith, 1967; Marx \& Winne, 1978; Wylie, 1989). As these researchers believed self-concept to be the sum total of an individual's self-perceptions, total self-concept was represented by a single score. But in their review of self-concept research, Shavelson, Hubner, \& Stanton (1976) integrated several definitions of self-concept. According to their integrated definition, selfconcept consists of a person's self-perceptions built through experience with - and interpretations of - one's environment. These self-perceptions are influenced mainly by evaluations by significant others, reinforcements, and attributions for one's own behavior. Shavelson et al. (1976) indicated that self-concept is both evaluative and descriptive, and that it has a multifaceted and hierarchical organization. Perceptions of personal behavior in certain situations are situated at the base of the hierarchy, inferences about self in broader domains (e.g.,

The International Journal of the Humanities

Volume 9, Issue 4, 2012, http://www.Humanities-Journal.com, ISSN 1447-9508

(C) Common Ground, Patricia Arnaiz, Felix Guillen, All Rights Reserved, Permissions:

cg-support@commongroundpublishing.com 
social, physical, and academic) are at the middle of the hierarchy, and a general self-concept is found at the apex. Nowadays it is generally accepted that self-concept functions in separate domains, i.e., self-beliefs are classified according to a specific field (Marsh, Byrne, \& Shavelson, 1988; Marsh \& Yeung, 1996, 1997, 1998; Valentine, DuBois, \& Cooper, 2004). Academic self-concept, for example, is an individual's self-perception of competence and his/her evaluative judgments in the academic domain (Mercer, 2011, p. 14).

There is sufficient research evidence to assert that self-concept influences behavior. What students feel about themselves will determine the way they deal with the challenges of the learning experience and also their relationship with others (Arnold, 2007). In their research with university students on another self-related construct, self-esteem, Brown and Smart (1991) observed that subjects who saw themselves as kind and helpful had prosocial behavior. They also noticed that those with high self-esteem had less difficulty preserving a positive view of themselves after failure. Subjects with low self-esteem, however, not only found it hard to reaffirm their self-image after failure, but also had a tendency to behave egotistically. Their conclusion may be of relevance for the purposes of our study: "self-presentations appear to play a critical role in guiding and regulating behavior" (Brown \& Smart, 1991, p. 373).

More than in any other discipline, in foreign language learning our self-concept can be severely damaged (Arnold, 2007; Mercer, 2011). Language learning is much more "ego-involving" than other areas of study (Horwitz, 2007). Due to the intrinsically social nature of the language learning process (Jones, 2008; Williams \& Burden, 1997), a very common problem in language learners is that they feel their ideas are not expressed properly in the target language and this may make them appear immature or foolish (Arnold \& Brown, 1999; Pellegrino, 2005). The use of a language of which the individual does not have full command, makes the self especially vulnerable (Tsui, 1996, p. 155). As Mercer (2011) accurately explains, it is that "visibility" characteristic of the language learning process, at least as regards the oral skill, that may turn it into an emotional ordeal.

Therefore, and if effective learning is what we are after, the relevance of psychological variables to learning should not be questioned. As Rodríguez, Plax and Kearney (1996: 297) have stated, "Affect is, by definition, an intrinsic motivator. Positive affect sustains involvement and deepens interest in the subject matter". Another author who has pointed in the same direction is Stevick (1980: 4), contending that success in foreign language learning depends more on what happens inside and between the people in the classroom than on materials and techniques. As Arnold and Brown (1999) explain, the most original techniques and the most appealing materials may turn out to be useless if negative emotional factors are present in the learning context.

One of the major areas of focus in connection with self-concept is students' past achievement experiences. As regards the nature and directionality of the relationship between academic self-concept and academic achievement, findings in psychology-based research have been contradictory. In the 70s, two models were suggested by Calsyn and Kenny (1977). The first one, "The Skill Development Model" suggests that academic achievement influences self-beliefs but that self-beliefs do not influence achievement. By contrast, the "Self-Enhancement Model" indicates that self-beliefs influence academic achievement but that academic achievement does not influence self-beliefs. A third model was later presented, the "Reciprocal Effects Model" (REM), in which self-concept and achievement are reciprocally related and mutually reinforcing (Marsh, 1990; Marsh \& Yeung, 1997). Therefore, according to the REM model, previous self-concept affects ensuing achievement, but previous achievement 
also affects ensuing self-concept development, and this contention has been supported by most studies (Guay, Marsh, \& Boivin, 2003; Liu, 2008; Marsh, Hau, \& Kong, 2002).

There seems to be no doubt that self-concept plays a key role in all learning contexts (Denissen, Zarrett \& Eccles, 2007; Hattie, 1992; Marsh \& Yeung, 1997). However, and in spite of the fact that self-related constructs appear in a wide variety of areas of SLA research, such as anxiety (Aida, 1994; Arnaiz \& Guillén, in press; Casado \& Dereshiwsky, 2001; Cheng, Horwitz, \& Schallert, 1999; Horwitz, 2001; Horwitz, Horwitz \& Cope, 1986), motivation (Dörnyei \& Ushioda, 2009), strategies (Woodrow, 2006), beliefs (Horwitz et al., 2004), metacognition (Wenden, 2001), Willingness to Communicate (WTC) (Yashima, Zenuk-Nishide \& Shimizu, 2004), and individual differences (Ehrman, Leaver, \& Oxford, 2003), the number of studies that have approached self-concept explicitly in language learners is low. Furthermore, in the literature reviewed, no self-concept studies have been found that have centred their attention on Spanish University English foreign language (EFL) students.

This research aims to shed light on the general self-concept levels of Spanish university students learning English as part of their degree. It will explore three of the five dimensions that make up the theoretical model selected: the academic, the social and the emotional dimensions. Although, as mentioned earlier, self-concept functions in separate domains and consequently, research into self-concept should be carried out at the domain-specific level (Marsh, Byrne, \& Shavelson, 1988; Marsh \& Yeung, 1996, 1997, 1998; Yeung \& Lee, 1999; Yeung \& Wong, 2004), there are also advantages in taking a more holistic perspective (Mercer, 2011). If we want to understand the nature and content of a learner's EFL selfconcept, it should be born in mind that learners often refer to other domains, which they perceive as important and related, when describing themselves as EFL learners. Thus, in order to understand how a learner may see himself /herself in a certain FL domain, it may be necessary first of all to take a holistic view of the learner, which will allow us to get information about a learner's self-beliefs in other domains.

Considering the difficulty Spanish students have traditionally encountered when studying English, and the fact that self-concept might be one of the factors that could be hindering the learning process, we wanted to carry out a preliminary study which collected data about this construct and analyzed some of the factors that might be influencing it. This study is timely in view of the Spanish education authorities' current interest in promoting foreign languages. The following research questions were developed for this study:

1. Do self-concept levels vary among learners with different marks in English?

2. Do self-concept levels vary among learners who had chosen English as a main subject and students for whom English was a non-elective obligatory subject?

3. Do self-concept levels vary among pre-service Primary English teachers and pre-service Primary Generalist, Music or Physical Education teachers?

4. How do self-concept levels relate to language level and mark? 


\section{Method}

\section{Participants}

Participants in this study consisted of 216 students enrolled in different English language courses in a Spanish university. Their language levels in English ranged from B1 to C1 ${ }^{1}$.

The sample consisted of 120 females (55.5\%) and 96 males (44.5\%). The respondents ranged in age from 18 to 39 , with a mean age of $20.39(S D=3.69)$ and came from six different degree programmes. There were 156 students from the Teacher Training Faculty, 59 of whom were studying to be Primary English teachers, which means English was their main chosen subject and was consequently a voluntary part of their curriculum, while 97 of them were studying to be Primary Generalist teachers, Physical Education teachers and Music teachers, for whom English was a non-elective degree requirement. The other two groups of students came from the Translation and Interpreting Faculty (30) and the Computer Science Faculty (30). The former had English as a main chosen subject, i.e. they were studying it voluntarily, while for the latter it was a prerequisite for graduation.

Prior to the study, all participants agreed to sign the consent form which indicated the aim and characteristics of the study.

\section{Instrument}

The questionnaire Autoconcepto Forma 5 [AF5: Self-concept form] (García \& Musitu, 2001) was used to measure students' self-concept. The scale consisted of 30 items and five subscales, but only the data for three of the subscales will be analyzed here: the academic self-concept, the social self-concept, and the emotional self-concept subscales.

The items were evaluated on a scale from 1 to 99 , "1" being the score which indicated total disagreement and "99" that of total agreement with the item. For the analysis of the results, the scale was converted into a scale from 1 to 10 .

Furthermore, a background questionnaire including information regarding students' language level, gender, age, and the last mark obtained in English was used.

\section{Procedure}

Permission was requested from the deans of the three Faculties involved to conduct the survey.

Once the principal investigator had explained the purpose of the study, the participants were asked to complete the background questionnaire. Subsequently, the Spanish students were given the questionnaire Autoconcepto Forma 5 [AF5: Self-concept form]. Participants had about 20 minutes to complete the questionnaires during class time.

\footnotetext{
${ }^{1}$ The language levels were established following The Common European Framework of Reference for Languages: Learning, Teaching, Assessment (CEFR) (2001), a guideline used to describe achievements of learners of foreign languages across Europe. The 2008 study by Martínez Baztán has addressed correspondence with The American Council on the Teaching of Foreign Languages (ACTFL) Guidelines. Thus, B1 would correspond to Intermediate Mid and Intermediate High, B2 would correspond to Intermediate High and Advanced Low, and C1, to Advanced Mid, Advanced High.
} 


\section{Data Analysis}

The analyses described below were performed using the SPSS 17.0 for Windows. Descriptive statistics were calculated to examine students' self-concept. The mean and standard deviations of the self-concept scale and subscales were computed for the whole group, and separated according to the marks obtained and the degree course selected by students. Participants were divided into three groups according to the marks obtained in English in the first semester of the academic year. One group was formed by low ability students (marks from 2 to 5), another group by average ability students (marks from 6 to 7), and a third group by high ability students (marks from 8 to 10). Finally, and in order to examine the relationship between the self-concept scale and subscales, on the one hand, and the variables level and mark, on the other hand, a correlation analysis was conducted on the full sample.

\section{Results}

Though the questionnaire Autoconcepto Forma 5 [AF5: Self-concept form] is a standardized instrument (with confirmed reliability, discrimination validity, and construct validity), the Cronbach's alpha coefficient of internal consistency for the scale was calculated. The internal consistency (reliability) of the total scale was .76, confirming that the items of the scale are clearly measuring the same construct. The internal consistency coefficients for the subscale scores were also acceptable, standing at .76 for academic self-concept, .74 for social selfconcept, and .81 for emotional self-concept.

The means and standard deviations of the global self-concept and the academic, social and emotional self-concepts of each ability group were computed (Table 1). No significant differences were observed between the three groups created.

Table 1: Mean Values and ANOVA Test of Self-concept Levels by Mark

\begin{tabular}{|l|c|c|c|c|c|}
\hline 3 groups & $\begin{array}{c}\mathbf{2}-\mathbf{5} \\
(n=\mathbf{5 1})\end{array}$ & $\begin{array}{c}\mathbf{6}-\mathbf{7} \\
(n=\mathbf{8 8})\end{array}$ & $\begin{array}{c}\mathbf{8}-\mathbf{1 0} \\
(n=\mathbf{6 2})\end{array}$ & & \\
\hline & Mean $(S D)$ & Mean $(S D)$ & Mean $(S D)$ & $F$ & $p$ \\
\hline Academic & $6.81(1.55)$ & $6.53(1.98)$ & $7.03(1.45)$ & 1.50 & .224 \\
\hline Social & $7.11(1.68)$ & $7.19(1.74)$ & $7.32(1.47)$ & .246 & .782 \\
\hline Emotional & $4.84(1.89)$ & $5.22(2.20)$ & $5.56(2.21)$ & 1.61 & .201 \\
\hline TOTAL & $6.84(.76)$ & $6.70(.90)$ & $6.78(.94)$ & .413 & .662 \\
\hline
\end{tabular}

Two independent sample $t$-test analyses were performed. The first was aimed at determining the differences in self-concept levels between the group who had English as a main subject (i.e. had chosen to study it voluntarily) and the group for whom it was non-elective degree requirement (i.e. a prerequisite for graduation). No statistical differences were revealed (Table 2). 
Table 2: Mean Values and T-test of Self-concept Subscales and Total Scores by Degree Type

\begin{tabular}{|l|c|c|c|}
\hline & $\begin{array}{c}\text { English MS } \\
(n=\mathbf{8 9})\end{array}$ & $\begin{array}{c}\text { English DR } \\
(n=\mathbf{1 2 5})\end{array}$ \\
\hline & Mean $(S D)$ & Mean $(S D)$ & $t(p)$ \\
\hline Academic & $6.74(1.79)$ & $6.81(1.72)$ & $-.286(.775)$ \\
Social & $7.18(1.80)$ & $7.25(1.57)$ & $-.295(.768)$ \\
Emotional & $5.04(2.07)$ & $5.32(2.14)$ & $-.951(.343)$ \\
Global & $6.72(.88)$ & $6.81(.87)$ & $-.757(.450)$ \\
\hline English MS = English as a main chosen subject; English DR = English as a degree \\
requirement
\end{tabular}

The second independent sample $t$-test analysis was carried out to discover the differences in self-concept levels between the group who had English as a main subject and the group who had it as a non-elective degree requirement. No statistical differences were detected (Table 3).

Table 3: Mean Values and T-test of Self-concept Subscales and Total Scores in Future Teachers

\begin{tabular}{|l|c|c|c|}
\hline & $\begin{array}{c}\text { PET } \\
(n=\mathbf{5 9})\end{array}$ & $\begin{array}{c}\text { PT } \\
(n=\mathbf{9 5})\end{array}$ & \\
\hline & Mean $(S D)$ & Mean $(S D)$ & $t(p)$ \\
\hline Academic & $7.00(1.82)$ & $7.04(1.58)$ & $-.148(.883)$ \\
Social & $7.32(1.58)$ & $7.45(1.50)$ & $-.501(.617)$ \\
Emotional & $4.89(2.17)$ & $5.11(2.08)$ & $-.645(.520)$ \\
Global & $6.84(.88)$ & $6.97(.83)$ & $-.883(.379)$ \\
\hline PET = future Primary English teachers ; PT = future Generalist, Music and Physical Edu- \\
cation teachers
\end{tabular}

In order to gain more understanding of students' self-concept, a correlation analysis was conducted on the full sample to investigate the relationships between the total scale and the academic, social and emotional subscales, on the one hand, and level and mark, on the other hand (Table 4).

With respect to level, significant negative correlations were detected between level and academic self-concept $(r=-.135)$ and level and the global score of the scale $(r=-.266)$; and a significant positive correlation was found between level and the social subscale $(r=.154)$.

As regards the variable mark, it was observed that it maintained a significant positive correlation with the emotional subscale $(r=.158)$. 
Table 4: Pearson Product-moment Correlations Among Self-concept Subscales the Total Scale, and Level, and Mark

\begin{tabular}{|l|c|c|c|c|c|c|}
\hline & Level & Mark & Academic & Social & Emotional & Global \\
\hline Level & & .076 & $-.135^{*}$ & $.154^{*}$ & .105 & $-.266^{* *}$ \\
\hline Mark & & & .079 & .090 & $.158^{*}$ & -.003 \\
\hline
\end{tabular}

\section{Discussion}

The study was mainly designed to gain insight into one important determinant of the foreign language learning process, students' self-concept, and its relation with the variables selected. Through a global self-concept scale, this preliminary study attempted to elucidate the selfconcept levels of university learners of English enrolled in different degrees with the aim of collecting data in a somewhat unexplored context, that of a university in Spain.

The results of the present study indicate that self-concept levels in students with different marks in English do not differ significantly. These findings contradict previous research showing that positive self-concept was linked to high academic achievement (Liu, 2009; Marsh, Smith \& Barnes, 1985).

In terms of differences between the self-concept levels of students with different levels of English, it was observed that those at a higher level have lower academic and global selfconcept levels. These findings corroborate Lin \& Sheen's (1996) statement that self-concept levels tend to be higher in the early stages of foreign language learning. For a possible interpretation of the results in the present study, we can refer to Horwitz's (2007) explanation about levels of anxiety -another self-related construct- in language learners. Learners very often experience anxiety when speaking a foreign language, and higher level learners may experience more anxiety than lower level learners when communicating in a foreign language, since they may be more sensitive to differences between their mature thoughts and the actual messages they are able to transmit, which may sometimes sound puerile. As learners advance in their language mastery, they may become more aware of their limitations and weaknesses. Likewise, how learners feel about themselves may vary across the different stages of the language learning process.

But findings to the contrary have also been encountered. In the research by Liu (2010) carried out with first-year university students who were receiving English instruction at the University of Taiwan, the correlation between academic self-concept and level was not only a positive correlation but also a strong one, so the higher ability group reported higher selfconcept levels than the lower ability group.

As for the self-concept levels in learners enrolled in different degrees, unexpectedly, no significant differences were found. Our interest in studying the self-concept in learners specializing to be future language teachers can be justified by the belief that a lack of self-concept now may become a lack of self-concept when they actually become teachers, and this may well limit the experiences they provide to their students. Again, due to the close connection between self-concept and anxiety, we can refer to Horwitz's theories related to the relevance of anxiety levels for language learners. Horwitz (1996) explains that the fact that a teacher completes the required course to become certified to teach English does not mean his/her language learning process has finished. Therefore, an anxious learner will probably become an anxious teacher, which means he or she will have difficulty in offering a comfortable 
classroom atmosphere that facilitates the use of the foreign language. His/her linguistic interactions and instructional strategies will be more controlled and predictable and this is very likely to deprive learners of the opportunity of enjoying a variety of classroom experiences. We consider that exactly the same theory can be applied to self-concept.

Without doubt, more research is needed in this direction. The figures obtained in this preliminary study should be complemented with figures obtained from research carried out with a domain-specific self-concept scale. As Marsh (2006, pp. 16) points out, "if researchers are specifically interested in self-concepts in particular academic subjects, then they should measure self-concepts with scales specific to those subjects" Future research could make use of the self-concept scale elaborated by Roncel Vega (2006) and administered to English learners of Spanish as a foreign language and Slovenian learners of Spanish as a foreign language (Roncel Vega, 2008).

Helping students to increase their self-concept levels should be one of the key aims of any foreign language program. Consequently, the more detailed the information provided about learners by this research area, the higher the probability of having successful foreign language teaching/learning sessions. As noted by Arnold and Brown (1999), the relationship between affect and language learning is bidirectional. Attention to affect can improve the language learning process and the language sessions can help building up students' affective side.

\section{Acknowledgement}

The authors would like to thank Heather Adams, ULPGC, for checking the final English version of the manuscript. 


\section{References}

Aida, Y. (1994). Examination of Horwitz, Horwitz and Cope's construct of foreign language anxiety: the case of students of Japanese. Modern Language Journal 78, 155-168.

Arnaiz, P., \& Guillén, F. (in press). Foreign language anxiety in a Spanish university setting: interpersonal differences. Revista Psicodidáctica.

Arnold, J. (2007). Self-concept as part of the affective domain in language learning. In F. Rubio (Ed.), Self-esteem and foreign language learning (pp. 13-29). Newcastle: UK. Cambridge Scholars Publishing.

Arnold, J., \& Brown, H. D. (1999). A map of the terrain. In J. Arnold (Ed.), Affect in language learning (pp. 1-27). Cambridge: Cambridge University Press.

Brown, J. D., \& Smart, S.A. (1991). The self and social conduct: Linking self-representations to prosocial behavior. Journal of Personality and Social Psychology, 60, 368-375.

Burnett, P. C., Pillay, H., \& Dart, B. C. (2003). The influences of conceptions of learning and learner self-concept on high school students' approaches to learning. School Psychology International, 24, 54-66.

Byrne, B. M. (1984). The general/academic self-concept nomological network: A review of construct validation research. Review of Educational Research, 54, 427-456.

Calsyn, R. J., \& Kenny, D. (1977). Self-concept of ability and perceived evaluation of others: Cause or effect of academic achievement. Journal of Educational Psychology, 69, 154-163.

Casado, M. A., \& Dereshiwsky, M. I. (2001). Foreign language anxiety of university students. College Student Journal, 35(4), 539-549.

Cheng, Y. S., Horwitz, E., \& Schallert, D. L. (1999). Language anxiety: differentiating writing and speaking components. Language Learning, 49(3), 417-446.

Coopersmith, S. A. (1967). The antecedents of self-esteem. San Francisco: Freeman.

Delugach, R. R., Bracken, B. A., Bracken, M. J., \& Schicke, M. C. (1992). Self-concept: Multidimensional construct exploration. Psychology in the Schools, 29, 213-223.

Denissen, J. J. A., Zarrett, N. R., \& Eccles, J. S. (2007). I like to do it, I'm able, and I know I am: Longitudinal couplings between domain-specific achievement, self-concept and interest. Child Development, 78(2), 430-447.

Dörnyei, Z., \& Ushioda, E. (2009). Motivation, language identity and the L2 self. Bristol: Multilingual Matters.

Ehrman, M. E., Leaver, B. L., \& Oxford, R. (2003). A brief overview of individual differences in second language learning. System 31(3), 313-330.

García, F., \& Musitu, G. (2001). AF5: Autoconcepto Forma 5 [AF5: Self-concept form 5] (2nd ed.). Madrid, Spain: TEA.

Guay, F., Marsh, H. W., \& Boivin, M. (2003). Academic self-concept and academic achievement: Developmental perspectives on their causal ordering. Journal of Educational Psychology, 95, 124-136.

Hattie, J. A. (1992). Self-concept. Hillsdale, NJ: Lawrence Erlbaum Associates.

Horwitz, E. K. (1996). Even teachers get the blues: Recognizing and alleviating non-native teachers' feelings of foreign language anxiety. Foreign Language Annals 29, 365-372.

Horwitz, E. K. (2001). Language anxiety and achievement. Annual Review of Applied Linguistics, 21, $112-126$.

Horwitz, E. K. (2007). Foreword. In F. Rubio (Ed.), Self-esteem and foreign language learning (pp. ix- xi). Newcastle: UK. Cambridge Scholars Publishing.

Horwitz, E. K., Horwitz, M. B., \& Cope, J. A. (1986). Foreign language classroom anxiety. Modern Language Journal, 70, 125-132.

Horwitz, E. K., Hsieh, P. H., Bonzo, J. D., Huang, D., Na, Y. H., \& Rubrecht, B. G. (2004). Case studies of language learners as a tool for helping teachers understand the experience of language learning. Hong Kong Journal of Applied Linguistics, 9, 1-14. 
James, W. (1896). Talks to teachers. New York: Norton.

Jones, J. F. (2008). A cultural context for language anxiety. EA Journal 21(2), 30-39.

Lin, H. P., \& Shen, S. S. (1996). Perceptual learning style preference for EFL students. Reports-Research (143). Taiwan: Chian Nan Junior Collegue of Pharmacy.

Liu, H. J. (2008). The relationship between EFL student academic self-concept and language performance. Feng Chia Journal of Humanities and Social Sciences, 17, 165-184.

Liu, H. J. (2009). Exploring changes in academic self-concept in ability-grouped English classes. Chang Gung Journal of Humanities and Social Sciences 2(2), 411-432.

Liu, H. J. (2010). The relation of academic self-concept to motivation among university EFL students. Feng Chia Journal of Humanities and Social Sciences, 20, 207-225.

Marsh, H. W. (1986). Verbal and math self-concepts: An internal/external frame of reference model. American Educational Research Journal, 23, 129-149.

Marsh, H. W. (1990). The structure of academic self-concept: The Marsh/Shavelson model. Journal of Educational Psychology, 82, 623-636.

Marsh, H. W. (1999). Academic Self Description Questionnaire - I: ASDQ I, University of Western Sydney, Self-concept Enhancement and Learning Facilitation Research Centre, Macarthur, Australia.

Marsh, H. W., Byrne, B. M., \& Shavelson, R. J. (1988). A multifaceted academic self-concept: its hierarchical structure and its relation to academic achievement. Journal of Educational Psychology, 80(3), 366-380.

Marsh, H. W., \& Craven, R. G. (2006). Reciprocal effects of self-concept and performance from a multidimensional perspective: Beyond seductive pleasure and unidimensional perspectives. Perspectives on Psychological Science, 1, 95-180.

Marsh, H. W., Hau, K. T., \& Kong, C. K. (2002). Multilevel causal ordering of academic self-concept and achievement: Influence of language of instruction (English compared with Chinese) for Hong Kong students. American Educational Research Journal, 39(3), 727-763.

Marsh, H. W, Smith, I. D., \& Barnes, J. (1985). Multidimensional self-concepts: Construct validation of responses by children. American Educational Research Journal 27, 89-117.

Marsh, H. W., \& Yeung, A. S. (1996). The distinctiveness of affects in specific school subjects: An application of confirmatory factor analysis with the national educational longitudinal survey of 1988. American Educational Research Journal, 33(3), 665-689.

Marsh, H. W., \& Yeung, A. S. (1997). Causal effects of academic self-concept on academic achievement: Structural equation models of longitudinal data. Journal of Educational Psychology, 89(1), 41-54.

Marsh, H. W., \& Yeung, A. S. (1998). Longitudinal structural equation models of academic self-concept and achievement: Gender differences in the development of maths and English constructs. American Educational Research Journal, 35(4), 705-738.

Martínez-Baztán, A. (2008). La evaluación oral: una equivalencia entre las guidelines de ACTFL y algunas escalas del MCER [Oral evaluation: an equivalence between ACTFL guidelines and some CEFR scales]. Unpublished doctoral dissertation. University of Granada, Granada, Spain.

Marx, R., \& Winne, P. H. (1978). Construct interpretations of three self-concept inventories. American Educational Research Journal, 15, 99-108.

McCroskey, J., Daly, J., Richmond, V., \& Falcione, R. (1977). Studies of the relationship between communication apprehension and self-esteem. Human Communication Research, 3(3), 269-277.

Mercer, S. (2011). Towards an understanding of language learner self-concept. London: Springer.

O'Mara, A. J., \& Marsh, H. W. (2006). Do self-concept interventions make a difference? A synergistic blend of construct validation and meta-analysis. Educational Psychologist, 41(3), 181-206. 
Pajares, F., \& Schunk, D. H. (2005). Self-efficacy and self-concept beliefs. In H. W. Marsh, R. G. Craven, \& D. M. McInerney (Eds.), International advances in self research (Vol. 2, pp. 95-121). Greenwich, Connecticut: Information Age Publishing.

Pellegrino, V. A. (2005). Study abroad and second language use: Constructing the self. Cambridge: Cambridge University Press.

Rodríguez, J. I., Plax, T. G., \& Kearney, P. (1996). Clarifying the relationship between teacher nonverbal immediacy and student cognitive learning: Affective learning as the central causal mediator. Communication-Education, 45, 293-305.

Roncel Vega, V. M. (2006). Cómo conocer a mis alumnos (anglosajones) de español desde el primer día de clase [How to get to know my (Anglosaxon) learners of Spanish in the first session]. redELE 7. Retrieved on 6 May 2011. http://www.educacion.gob.es/redele/revista7/roncel.pdf

Roncel Vega, V. M. (2008). Autoconcepto, motivación y ansiedad en el aula de idiomas [Self-concept, motivation and anxiety in the language classroom]. marcoELE, 7. Retrieved on 10 May 2011. http://marcoele.com/descargas/7/roncel_autoconcepto-motivacion.pdf

Shavelson, R. J., Hubner, J. J., \& Stanton, G. C. (1976). Validation of construct interpretations. Review of Educational Research, 46, 407-441.

Stevick, E. W. (1980). Teaching languages: A way and ways. Rowley, MA: Newbury House.

Tsui, A. (1996). Reticence and anxiety in second language learning. In K. Bailey, \& D. Nunan (Eds.), Voices from the language classroom: qualitative research in second language education (pp. 145-167). Cambridge: Cambridge University Press.

Valentine, J. C., DuBois, D. L., \& Cooper, H. (2004). The relations between self-beliefs and academic achievement: A systematic review. Educational Psychologist, 39, 111-133.

Wenden, A. (2001). Metacognitive knowledge and language learning. Applied Linguistics, 19(4), $515-537$.

Williams, M., \& Burden, R. L. (1997). Psychology for language teachers. Cambridge: Cambridge University Press.

Woodrow, L. J. (2006). A model of adaptive language learning. The Modern Language Journal, 90(3), 297-319.

Wylie, R. C. (1989). Measures of self-concept. Lincoln: University of Nebraska Press.

Yashima, T., Zenuk-Nishide, L., \& Shimizu, K. (2004). The influence of attitudes and affect on willingness to communicate and second language communication. Language Learning, 54(1), $119-152$.

Yeung, A. S., \& Lee, F. L. (1999). Self-concept of high school students in China: Confirmatory factor analysis of longitudinal data. Educational and Psychological Measurement, 59, 431-450.

Yeung, A. S., \& Wong, E. K. P. (2004). Domain specificity of trilingual teachers' verbal self-concepts. Journal of Educational Psychology 96(2), 360-368.

Zimmerman, B. J. (1996). Misconceptions, problems, and dimensions in measuring self-efficacy, Paper presented at the annual meeting of the American Educational Research Association, New York.

\section{About the Authors}

\section{Dr. Patricia Arnaiz}

Patricia Arnaiz focused her PhD Thesis (2001) on the output of Spanish learners of English as a foreign language. She has done different studies on this particular topic and has written several handbooks for University students. She is also interested in examining the role affective variables such as anxiety and self-concept can have in the foreign language learning process. 
THE INTERNATIONAL JOURNAL OF THE HUMANITIES

Dr. Felix Guillen

Félix Guillén gained his $\mathrm{PhD}$ in Psychology in 1991 and his subject field is Basic Psychology. He has carried out several studies on anxiety and self-concept in different social and educational contexts. He has written several books on Psychology. 